\title{
A meta-analysis of the effects of experimental warming on soil carbon and nitrogen dynamics on the Tibetan Plateau
}

\author{
Xian-Zhou Zhang ${ }^{1}$, Zhen-Xi Shen ${ }^{1}$, Gang Fu* \\ Lhasa Plateau Ecosystem Research Station, Key Laboratory of Ecosystem Network Observation and Modeling, Institute of Geographic Sciences and Natural \\ Resources Research, Chinese Academy of Sciences, Beijing 100101, China
}

\section{A R T I C L E I N F O}

\section{Article history:}

Received 30 May 2014

Received in revised form 25 October 2014

Accepted 23 November 2014

Available online 29 November 2014

\section{Keywords:}

Global warming

Increased temperature

Microbial biomass

Response ratio

\begin{abstract}
A B S T R A C T
Alpine ecosystems at high altitudes and latitudes are notably sensitive to climatic warming and the Tibetan Plateau is a widely distributed alpine ecosystem. The magnitude of climatic warming on the Tibetan Plateau is expected to be considerably greater than the global average. However, a synthesis of the experimental warming soil carbon and nitrogen data is still lacking and whether forest soils are more sensitive to warming than grassland soils remains unclear. In this study, we used a meta-analysis approach to synthesise 196 observations from 25 published studies on the Tibetan Plateau. Warming significantly increased microbial biomass carbon (MBC) by $14.3 \%$ (95\% CI: 2.9-24.6\%), microbial biomass nitrogen (MBN) by 20.1\% (95\% CI: 2.0-45.1\%), net nitrogen mineralization by $49.2 \%(95 \% \mathrm{CI}: 38.1-62.3 \%)$ and net nitrification by $56.0 \%$ (95\% CI: 51.4-66.1\%), but did not significantly affect soil carbon (95\% CI: -13.9 to $2.7 \%$ ) or nitrogen ( $95 \% \mathrm{CI}$ : -12.4 to $2.6 \%$ ). The mean annual air temperature was negatively correlated with the warming effects on MBC and MBN. Grasslands exhibited significant MBC and MBN responses to warming. Specifically, soil microbial biomass was more responsive to warming in colder environments. Moreover, forest soils are not always more sensitive to warming than grassland soils as previous studies have suggested. These findings indicate that clarifying the effect of warming on alpine soils need consider ecosystem types and their local climate.
\end{abstract}

(c) 2014 Elsevier B.V. All rights reserved.

\section{Introduction}

Alpine ecosystems at high altitudes and latitudes are notably sensitive to climatic change, although there are many uncertainties in how these systems will respond to climatic change (IPCC, 2007; Shen et al., 2014). The Tibetan Plateau, a widely distributed alpine ecosystem, is one of the most sensitive regions to global climatic change worldwide (Chen et al., 2013; Fu et al. in press; Miehe et al., 2011; Zhang et al., 2000). The magnitude of warming in alpine regions is predicted to be much greater than the global average (IPCC, 2007). The warming amplitude increases with increasing altitude on this Plateau (Liu and Chen 2000; Yao et al., 2000). Field experiments have analysed the potential effects of warming on the alpine soils on the Tibetan Plateau (Fu et al., 2012; Li et al., 2011; Rui et al., 2011; Xu et al., 2010a; Yu et al., 2014). However, a synthesis of the experimental warming data is still unavailable and thus, the

\footnotetext{
* Corresponding author. Tel.: +8610 64888176; fax: +861064854230.

E-mail address: fugang09@126.com (G. Fu).

1 The author contributed equally to this work.
}

general tendency of the warming effects remains unclear for alpine soils across this Plateau.

The microbial biomass of carbon (MBC) and nitrogen (MBN) in soil are important components in terrestrial ecosystem carbon and nitrogen cycling and serve as sources (mineralization) or sinks (immobilisation) of labile carbon and nitrogen pools (Bai et al., 2013; Lu et al., 2013a). The microbial biomass in soil responds quickly to changes in the soil temperature (Alvarez et al., 1995). MBC is likely to be more responsive to warming than MBN across all terrestrial ecosystems (Bai et al., 2013; Lu et al., 2013a). The nonsignificant response of MBN to warming may result from the limited availability of carbon sources (Bai et al., 2013), while warming significantly increases the dissolved organic carbon (DOC), an important carbon source for soil microorganisms (Lu et al., 2013a). Therefore, the underlying mechanism causing the non-significant effect that warming has on MBN remains unclear.

Both the increase in soil respiration $\left(R_{\mathrm{s}}\right)$ (Lin et al., 2011b; Lu et al., 2013b; Shi et al., 2012; Xiong et al., 2010; Xu et al., 2010b) and the decline in litter quantity (Li et al., 2011; Lin et al., 2011a; Luo et al., 2009) contribute to the decrease in the soil carbon and nitrogen pools on the Tibetan Plateau. The increase in MBC caused 
by warming also implies that warming may accelerate organic matter decomposition in soil (Wang et al., 2011), while inconsistent responses of $\mathrm{MBC}$ and $\mathrm{MBN}$ to warming have been reported on this Plateau (Chen et al., 2010; Fu et al., 2012; Wang et al., 2011). Warming-induced increases in the net nitrogen mineralization and nitrification rates increased the nitrogen availability in soil (Bai et al., 2013; Rustad et al., 2001), which in turn increased plant biomass accumulation (Fu et al., in press; Rustad et al., 2001) and soil microbial biomass (Yin et al., 2012; Yu et al., 2014). Furthermore, a warming-induced increase in plant biomass may more or less counterbalance the warming-induced increases in $R_{\mathrm{S}}$ and decreases in litter quantity (Lu et al., 2013a). However, the effects of warming on plant biomass were negative (Klein et al., 2007; Yang et al., 2013), positive (Li et al., 2011; Wang et al., 2012) or neutral (Fu et al., 2013) in alpine ecosystems. The variability between these two factors may result in the inconsistent response of soil carbon and nitrogen to warming on the Tibetan Plateau (Chen et al., 2010; Shi et al., 2012; Wang et al., 2011).

Forests show stronger responses to warming than grasslands in terms of soil respiration and soil nitrogen availability (Bai et al., 2013; Lu et al., 2013a; Rustad et al., 2001), which may be related to the fact that most observations in forests were conducted in more temperature-limited areas (Bai et al., 2013). However, grasslands may generally have lower air temperatures than forests in alpine regions on the Tibetan Plateau (Luo et al., 2010; Shen et al., 2014; Yin et al., 2013). Therefore, it remains unclear whether forests are always more sensitive to warming than grasslands in alpine regions.

In this study, we compiled data from 25 published experimental warming studies across the Tibetan Plateau. The goal was (1) to identify quantitatively the general tendencies caused by warming effects on 18 variables related to the soil carbon and nitrogen pools

Table 1

Site characteristics and response variables from a meta-analysis of 25 studies on the Tibetan Plateau.

\begin{tabular}{|c|c|c|c|c|c|c|c|}
\hline Site & Latitude & Longitude & $\begin{array}{l}\text { Altitude } \\
(\mathrm{m})\end{array}$ & $\begin{array}{l}\text { MAT } \\
\left({ }^{\circ} \mathrm{C}\right)\end{array}$ & MAP (mm) & Response variables & References \\
\hline Damxung grassland station & 30.50 & 91.07 & 4300 & 1.3 & 476.8 & MBC, MBN & $\begin{array}{l}\text { Fu et al., } \\
2012\end{array}$ \\
\hline Eastern slope of Mount Gongga & 29.83 & 101.88 & 3000 & 3.8 & 1940 & Plant biomass, root length & $\begin{array}{l}\text { Yang et al., } \\
2013\end{array}$ \\
\hline Ebao, Qilian County & 37.97 & 100.92 & 3512 & 1 & 409 & Soil $\mathrm{C}$ and $\mathrm{N}, \mathrm{MBC}, \mathrm{MBN}$ & $\begin{array}{l}\text { Heng, } \\
2011\end{array}$ \\
\hline \multirow[t]{2}{*}{ Fenghuoshan region } & \multirow[t]{2}{*}{34.73} & \multirow[t]{2}{*}{93.07} & \multirow[t]{2}{*}{$4600-4800$} & \multirow[t]{2}{*}{-5.3} & \multirow[t]{2}{*}{269.7} & Soil $\mathrm{C}$ and $\mathrm{N}, \mathrm{MBC}, \mathrm{MBN}$ & $\begin{array}{l}\text { Li et al., } \\
2010\end{array}$ \\
\hline & & & & & & Soil C and N, MBC, MBN, catalase, urease, protease & $\begin{array}{l}\text { Li et al., } \\
2011\end{array}$ \\
\hline \multirow[t]{3}{*}{$\begin{array}{l}\text { Haibei alpine meadow ecosystem } \\
\text { research station }\end{array}$} & \multirow[t]{3}{*}{37.62} & \multirow[t]{3}{*}{101.20} & \multirow[t]{3}{*}{3200} & \multirow[t]{3}{*}{-2} & \multirow[t]{3}{*}{500} & Soil respiration & $\begin{array}{l}\text { Lin et al., } \\
2011 b\end{array}$ \\
\hline & & & & & & Soil N, MBC, MBN, DOC, DON, $\mathrm{NH}_{4}{ }^{+}-\mathrm{N}$ and $\mathrm{NO}_{3}{ }^{-}-\mathrm{N}$ & $\begin{array}{l}\text { Rui et al., } \\
2011\end{array}$ \\
\hline & & & & & & Net $\mathrm{N}$ mineralization & $\begin{array}{l}\text { Wang } \\
\text { et al., } 2012\end{array}$ \\
\hline \multirow[t]{2}{*}{$\begin{array}{l}\text { Hongyuan alpine ecosystem research } \\
\text { station }\end{array}$} & \multirow[t]{2}{*}{32.45} & \multirow[t]{2}{*}{102.37} & \multirow[t]{2}{*}{3561} & \multirow[t]{2}{*}{1.1} & \multirow[t]{2}{*}{752.4} & Polyphenol oxidase, urease & $\begin{array}{l}\text { Liu et al., } \\
\text { 2011a }\end{array}$ \\
\hline & & & & & & MBC, MBN & $\begin{array}{l}\text { Wang } \\
\text { et al., } 2011\end{array}$ \\
\hline Kakagou, Songpan County & 32.85 & 103.55 & 3400 & 2.8 & 718 & $\begin{array}{l}\text { Soil } \mathrm{N}, \mathrm{MBC}, \mathrm{MBN} \text {, net } \mathrm{N} \text { mineralization, } \mathrm{NH}_{4}{ }^{+}-\mathrm{N} \text { and } \\
\mathrm{NO}_{3}{ }^{-}-\mathrm{N} \text {, soil respiration } \\
\text { Plant biomass }\end{array}$ & $\begin{array}{l}\text { Shi et al., } \\
2012 \\
\text { Shi et al., } \\
2010\end{array}$ \\
\hline \multirow[t]{5}{*}{ Maoxian ecological station } & \multirow[t]{5}{*}{31.68} & \multirow[t]{5}{*}{103.88} & \multirow[t]{5}{*}{1820} & \multirow[t]{5}{*}{8.9} & \multirow[t]{5}{*}{920} & Soil $\mathrm{C}$ and $\mathrm{N}, \mathrm{MBC}, \mathrm{MBN}, \mathrm{NH}_{4}{ }^{+}-\mathrm{N}$ and $\mathrm{NO}_{3}{ }^{-}-\mathrm{N}$ & $\begin{array}{l}\text { Chen et al., } \\
2010\end{array}$ \\
\hline & & & & & & $\begin{array}{l}\text { Soil } \mathrm{C} \text { and } \mathrm{N}, \mathrm{MBC}, \mathrm{MBN}, \mathrm{NH}_{4}{ }^{+}-\mathrm{N} \text { and } \mathrm{NO}_{3}{ }^{-}-\mathrm{N} \text {, root } \\
\text { length }\end{array}$ & $\begin{array}{l}\text { Liu et al., } \\
\text { 2011b }\end{array}$ \\
\hline & & & & & & $\mathrm{MBC}, \mathrm{MBN}, \mathrm{NH}_{4}{ }^{+}-\mathrm{N}$ and $\mathrm{NO}_{3}{ }^{-}-\mathrm{N}$, soil respiration & $\begin{array}{l}\text { Xiong } \\
\text { et al., } 2010\end{array}$ \\
\hline & & & & & & $\begin{array}{l}\text { Soil } \mathrm{C} \text { and } \mathrm{N}, \mathrm{MBC}, \mathrm{MBN} \text {, net } \mathrm{N} \text { mineralization and } \\
\text { nitrification, } \mathrm{NH}_{4}^{+}-\mathrm{N} \text { and } \mathrm{NO}_{3}{ }^{-}-\mathrm{N} \text {, root length }\end{array}$ & $\begin{array}{l}\text { Yin et al., } \\
2012\end{array}$ \\
\hline & & & & & & $\begin{array}{l}\text { Net } \mathrm{N} \text { mineralization, polyphenol oxidase, urease, plant } \\
\text { biomass }\end{array}$ & $\begin{array}{l}\text { Yin et al., } \\
2013\end{array}$ \\
\hline \multirow[t]{7}{*}{$\begin{array}{l}\text { Miyaluo experimental forest of Lixian } \\
\text { County }\end{array}$} & \multirow[t]{7}{*}{31.58} & \multirow[t]{7}{*}{102.58} & 3150 & 8 & $600-1100$ & $\begin{array}{l}\text { Soil C and } \mathrm{N} \text {, polyphenol oxidase, catalase, invertase, } \\
\text { urease, protease }\end{array}$ & $\begin{array}{l}\text { Pan et al., } \\
2008\end{array}$ \\
\hline & & & & & & Plant biomass & $\begin{array}{l}\text { Han et al., } \\
2009\end{array}$ \\
\hline & & & & & & $\begin{array}{l}\mathrm{MBC}, \mathrm{MBN}, \mathrm{DOC}, \mathrm{DON} \text {, net nitrification, } \mathrm{NH}_{4}{ }^{+}-\mathrm{N} \text { and } \\
\mathrm{NO}_{3}{ }^{-}-\mathrm{N} \text {, polyphenol oxidase, catalase, invertase, } \\
\text { urease }\end{array}$ & $\begin{array}{l}\text { Xu et al., } \\
2010 a\end{array}$ \\
\hline & & & & & & Soil $\mathrm{C}$ and $\mathrm{N}$, soil respiration & $\begin{array}{l}\text { Xu et al., } \\
2010 b\end{array}$ \\
\hline & & & & & & Net $\mathrm{N}$ mineralization, plant biomass & $\begin{array}{l}\text { Xu et al., } \\
2012\end{array}$ \\
\hline & & & & & & Plant biomass & $\begin{array}{l}\text { Yin et al., } \\
2008 \mathrm{a}\end{array}$ \\
\hline & & & & & & Plant biomass & $\begin{array}{l}\text { Yin et al., } \\
2008 b\end{array}$ \\
\hline $\begin{array}{l}\text { Xainza alpine steppe and wetland } \\
\text { ecosystem observation and experiment } \\
\text { station }\end{array}$ & 30.95 & 88.7 & 4675 & 0 & 300 & Soil respiration & $\begin{array}{l}\text { Lu et al., } \\
2013 b\end{array}$ \\
\hline
\end{tabular}

MBC: soil microbial biomass carbon; MBN: soil microbial biomass nitrogen; DOC: dissolved organic carbon; DON: dissolved organic nitrogen. 


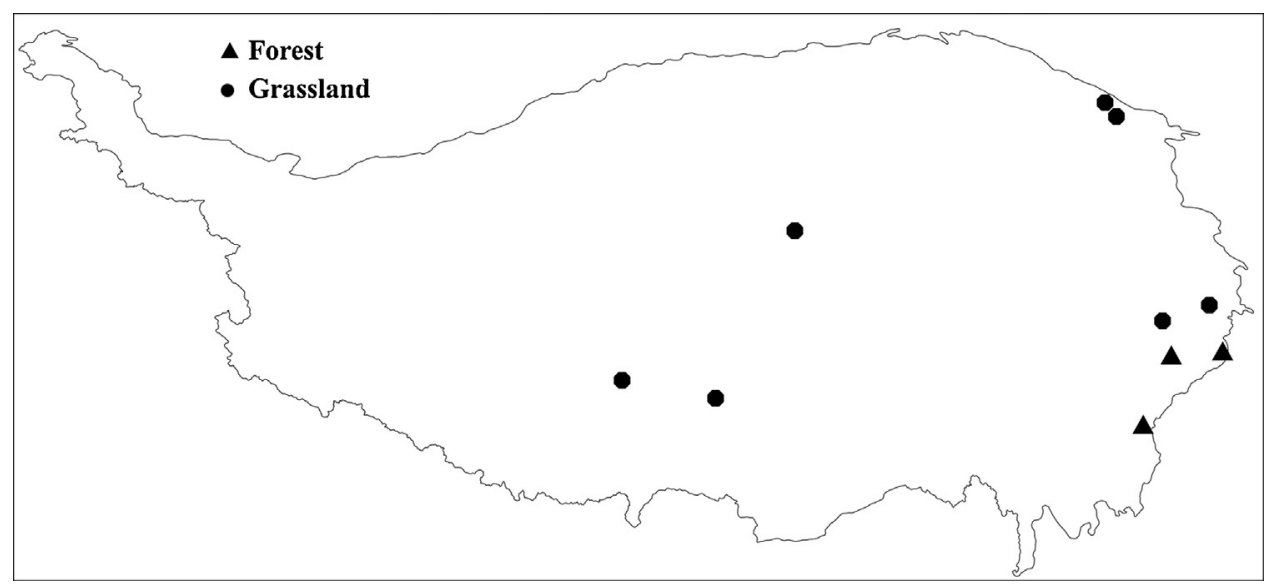

Fig. 1. Study sites and vegetation types from a meta-analysis of 25 studies on the Tibetan Plateau.

in the "Earth's Third Pole" and (2) to determine whether forests are not always more sensitive to warming than grasslands.

\section{Materials and methods}

\subsection{Data compilation}

We sought papers and theses published prior to September, 2013 using the Web of Science and the China National Knowledge Infrastructure (Table S1). The compiled database included biomass parameters [plant biomass (PB) and root length], soil carbon pools (soil carbon, MBC, and DOC), soil nitrogen pools [soil nitrogen, MBN, dissolved organic $\mathrm{N}$ (DON), ammonium nitrogen $\left(\mathrm{NH}_{4}{ }^{+}-\mathrm{N}\right)$ and nitrate nitrogen $\left.\left(\mathrm{NO}_{3}{ }^{-}-\mathrm{N}\right)\right], R_{\mathrm{s}}$, net nitrogen mineralization and nitrification rates, and soil enzymes (polyphenol oxidase, catalase, invertase, urease and protease) (Table 1).

Our criteria were as follows: only studies conducted on the Tibetan Plateau were included; at least one of the variables considered here was measured; studies with laboratory incubation, temperature gradients and growth chambers were excluded and only field warming experimental studies were included; only data from control and warming treatments were used for multifactor experiments; only the latest results were used for multiple observations at different times from the same study site because the observations should be independent in the metaanalysis (Hedges et al., 1999; Rosenberg et al., 2000); means, standard deviations (or standard errors), and sample sizes were directly provided or could be calculated from the studies; multiple soil depths, warming magnitudes or ecosystem types were treated as independent variables (Bai et al., 2013; Lu et al., 2013a).

The warming duration was calculated in months. The data were extracted using GetData software if the studies provided the data in figures (Fu et al., in press). We grouped all of the studies into those analysing forests and grasslands at the ecosystem level and into those analysing trees and grasses at the species level (Fig. 1).

\subsection{Statistical analyses}

The METAWIN 2.1 software (Sinauer Associates Inc., Sunderland, MA, USA) (Rosenberg et al., 2000) was used to perform metaanalysis in this study. The natural logarithm of the response ratio $(R)$ was used as the effect size (Hedges et al., 1999), see Eq. (1): $\log _{\mathrm{e}} R=\log _{\mathrm{e}}\left(\overline{\overline{X_{\mathrm{t}}}}\right)=\log _{\mathrm{e}}\left(\overline{X_{\mathrm{t}}}\right)-\log _{\mathrm{e}}\left(\overline{X_{\mathrm{c}}}\right)$

where $\overline{X_{\mathrm{c}}}$ and $\overline{X_{\mathrm{t}}}$ are the mean values in the control and warming treatments, respectively.

For each study, the inverse of the pooled variance $(1 / v)$ was used as the weighting factor $(w)$ in Eq. (2):

$v=\frac{S_{\mathrm{t}}^{2}}{n_{\mathrm{t}} \overline{X_{\mathrm{t}}^{2}}}+\frac{S_{\mathrm{c}}^{2}}{n_{\mathrm{c}} \overline{X_{\mathrm{c}}^{2}}}$

where $S_{\mathrm{c}}^{2}$ and $S_{\mathrm{t}}^{2}$ are the standard deviations in the control and warming treatments, respectively; $n_{\mathrm{c}}$ and $n_{\mathrm{t}}$ are the sample sizes in the control and warming treatments, respectively.

Therefore, the mean effect size $\left(\overline{\log _{\mathrm{e}} R}\right)$ for all observations were obtained, see Eq. (3):

$\overline{\log _{\mathrm{e}} R}=\frac{\sum_{i=1}^{m} w_{\mathrm{i}} \log _{\mathrm{e}} R_{\mathrm{i}}}{\sum_{i=1}^{m} w_{\mathrm{i}}}$

where $w_{\mathrm{i}}$ and $\log _{\mathrm{e}} R_{\mathrm{i}}$ are $w$ and $\log _{\mathrm{e}} R$ of the $i$ th observation, respectively.

We used a fixed effects model, which is the simplest data structure model for meta analyses, to test whether warming had a significant effect on a specific variable across forests and grasslands (Rosenberg et al., 2000). The mean effect size and 95\% bootstrap confidence intervals (CI) were generated. For each variable, the warming effect on this variable is statistically significant if the 95\% bootstrap CI did not bracket zero (Wan et al., 2001).

A fixed effects model with a grouping variable was used to compare responses between forests and grasslands and between some related variables (i.e., $\mathrm{MBC}$ vs. $\mathrm{MBN}, \mathrm{NH}_{4}{ }^{+}-\mathrm{N}$ vs. $\mathrm{NO}_{3}{ }^{-}-\mathrm{N}$, and net nitrogen mineralization rate vs. net nitrification rate), which is analogous to ANOVA (Rosenberg et al., 2000). In the grouping models, the mean effect size of a specific group can be calculated using only the observations of that group (Rosenberg et al., 2000). Similarly, the warming effect is statistically significant if the 95\% bootstrap CI did not cover zero for each group (Rosenberg et al., 2000).

A random effects model with a continuous variable ( $>15$ observations) was used to examine the relationships between the mean effect size of warming and the warming duration, increased soil temperature and mean annual air temperature (Rosenberg et al., 2000). A weighted least squares regression was used to determine the relationship between the effect sizes and the independent 
(a) Forest

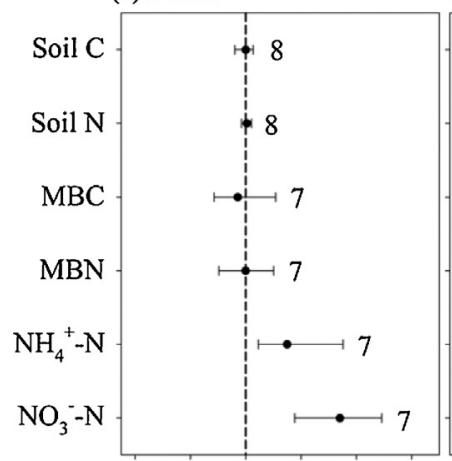

(b) Grassland

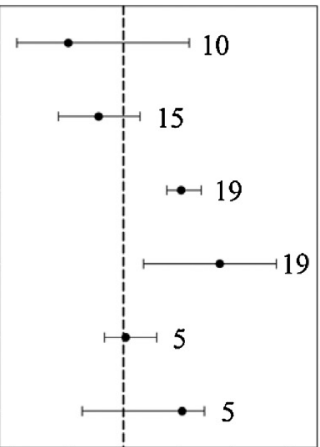

(c) Overall

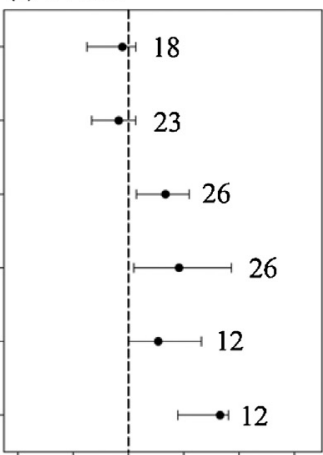

$\begin{array}{llllllllllllllllll}-0.4 & -0.2 & 0.0 & 0.2 & 0.4 & 0.6 & -0.4 & -0.2 & 0.0 & 0.2 & 0.4 & 0.6 & -0.4 & -0.2 & 0.0 & 0.2 & 0.4 & 0.6\end{array}$

Effect size

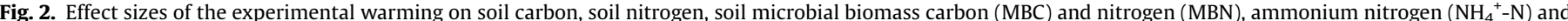

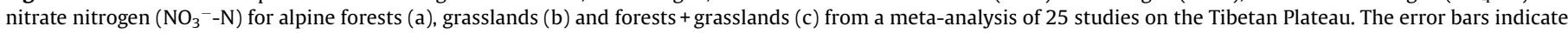

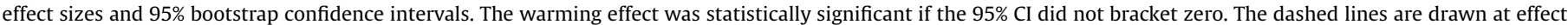
size $=0$. The sample size for each variable is shown next to the bar.

variables for a continuous model (Rosenberg et al., 2000). A significant regression coefficient (i.e., slope) indicates that a significant amount of the variation between the effect sizes can be explained by an independent variable (Rosenberg et al., 2000).

For grouping and continuous models, the total heterogeneity $\left(Q_{T}\right)$ of the effect sizes can be partitioned into the variation among the effect sizes, which is explained by the model $\left(Q_{M}\right)$ and not explained by the model $\left(Q_{E}\right)$ (Rosenberg et al., 2000). For a grouping model, a significant $Q_{M}$ indicates that significant differences in the mean effect sizes are found among the groups, while a significant $Q_{M}$ indicates that a significant part of the variation among effect sizes can be explained by an independent variable in a continuous model (Rosenberg et al., 2000).

All statistical significance was examined at $P<0.05$.

\section{Results}

Experimental warming did not affect the soil carbon in forests (mean effect size $=-0.0001 ; 95 \% \mathrm{CI}:-0.039$ to 0.027 ) or grasslands (mean effect size $=-0.1995 ; 95 \% \mathrm{CI}:-0.385$ to 0.237 ) (Fig. $2 \mathrm{a}$ and

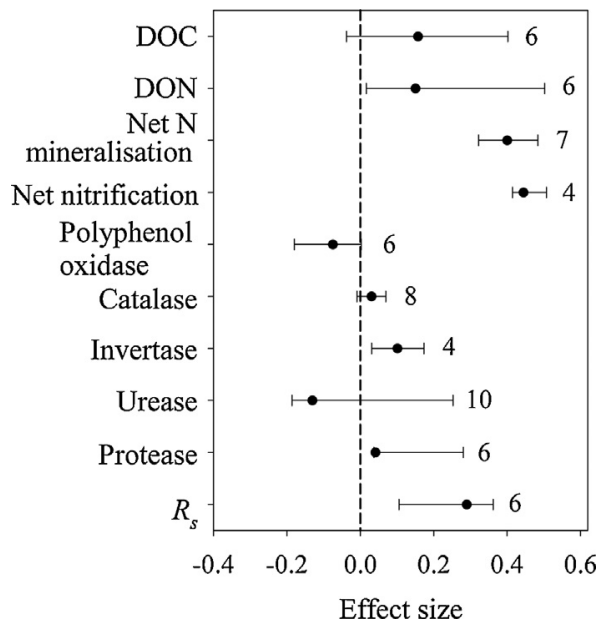

Fig. 3. Sizes of the effects of the experimental warming on dissolved organic carbon $(D O C)$ and nitrogen (DON) in soil, net nitrogen mineralization, net nitrification, polyphenol oxidase, catalase, invertase, urease, protease and soil respiration $\left(R_{\mathrm{s}}\right)$ from a meta-analysis of 25 studies on the Tibetan Plateau. The error bars indicate the effect sizes and the $95 \%$ bootstrap confidence intervals. The warming effect was statistically significant if the $95 \% \mathrm{CI}$ did not bracket zero. The dash lines are drawn at effect size $=0$. The sample size for each variable is shown next to the bar. b). Similarly, forests (mean effect size $=0.004 ; 95 \% \mathrm{CI}$ : -0.015 to 0.021 ) and grasslands (mean effect size $=-0.09 ; 95 \% \mathrm{CI}$ : -0.235 to 0.060 ) did not experience a significant effect from experimental warming on the soil nitrogen (Fig. $2 \mathrm{a}$ and $\mathrm{b}$ ). Forests and grasslands had significantly different responses of $\mathrm{MBC}\left(Q_{\mathrm{M}}=91.4, P<0.001\right)$, MBN $\left(Q_{M}=68.8, P<0.001\right), \mathrm{NH}_{4}{ }^{+}-\mathrm{N}\left(Q_{\mathrm{M}}=12.7, P<0.001\right)$ and $\mathrm{NO}_{3}{ }^{-}-\mathrm{N}\left(Q_{\mathrm{M}}=4.5, P<0.05\right)$ due to experimental warming (Fig. $2 \mathrm{a}$ and $\mathrm{b}$ ). In detail, the MBC and MBN increased by $23.1 \%(95 \% \mathrm{CI}$ : 16.9-32.4\%) and 41.5\% (95\% CI: 7.5-73.7\%), respectively, in grasslands. In contrast, forests had no responses $(95 \% \mathrm{CI}$ : -0.114 to 0.108 for MBC; $95 \% \mathrm{CI}$ : -0.098 to 0.101 for $\mathrm{MBN})$. The soil $\mathrm{NH}_{4}{ }^{+}-\mathrm{N}$ and $\mathrm{NO}_{3}{ }^{-}-\mathrm{N}$ increased by $16.2 \%$ (95\% CI: $4.7-42.2 \%$ ) and $40.5 \%$ (95\% CI: $19.4-63.5 \%$ ), respectively, in forests due to the effects of warming, while grasslands had no responses ( $95 \% \mathrm{CI}$ : -0.069 to 0.119 for $\mathrm{NH}_{4}{ }^{+}-\mathrm{N}$; $95 \% \mathrm{CI}:-0.149$ to 0.292 for $\left.\mathrm{NO}_{3}{ }^{-}-\mathrm{N}\right)$.

In both forests and grasslands, the experimental warming had no effects on the $\mathrm{NH}_{4}{ }^{+}-\mathrm{N}$ (mean effect size $=0.108 ; 95 \% \mathrm{CI}$ : -0.002 to 0.264 ), soil carbon (mean effect size $=-0.02 ; 95 \% \mathrm{CI}$ :

\section{Table 2}

Relationships between the sizes of the effect of the experimental warming on the carbon and nitrogen pools in soil, soil microbial biomass carbon and nitrogen, warming duration, increased soil temperature and mean annual air temperature based on a random effects model with a continuous variable meta-analysis on the Tibetan Plateau.

\begin{tabular}{lcccccc}
\hline Variables & $Q_{\mathrm{M}}$ & $Q_{\mathrm{E}}$ & $Q_{\mathrm{T}}$ & Slope & $P$ & $n$ \\
\hline Warming duration & & & & & & \\
Soil C & 0.05 & 25.60 & 25.65 & 0.02 & 0.824 & 18 \\
Soil N & 0.01 & 16.34 & 16.35 & 0.01 & 0.905 & 23 \\
Soil microbial biomass C & 0.46 & 23.54 & 24.01 & 0.03 & 0.496 & 26 \\
Soil microbial biomass N & 0.24 & 25.99 & 26.23 & -0.04 & 0.627 & 26 \\
& & & & & & \\
Raised soil temperature & & & & & & \\
Soil N & 0.20 & 10.77 & 10.96 & 0.01 & 0.658 & 19 \\
Soil microbial biomass C & 0.81 & 17.23 & 18.04 & -0.03 & 0.369 & 22 \\
Soil microbial biomass N & 3.10 & 23.00 & 26.10 & -0.09 & 0.079 & 22 \\
& & & & & & \\
Mean annual air temperature & & & & & & \\
Soil C & 0.004 & 37.94 & 37.94 & -0.0003 & 0.949 & 18 \\
Soil N & 0.43 & 18.67 & 19.10 & 0.003 & 0.511 & 23 \\
Soil microbial biomass C & 11.62 & 26.15 & 37.78 & -0.02 & 0.001 & 26 \\
Soil microbial biomass N & 9.53 & 28.54 & 38.07 & -0.04 & 0.002 & 26 \\
\hline
\end{tabular}

$Q_{\mathrm{T}}$ : total heterogeneity of the sizes of the effects among studies; $Q_{\mathrm{E}}$ : the residual error or the variation is not explained by the continuous randomised-effects model; $Q_{M}$ : the variation is explained by the continuous randomised-effects model; Slope: regression coefficients; $P$ : the statistical probability; $n$ : the number of the observations used in the meta-analysis. A significant $Q_{M}$ and slope shows that a significant part of the variation among effect sizes can be explained by an independent variable. The relationships were significant when $P<0.05$. 
-0.15 to 0.03 ) and nitrogen (mean effect size $=-0.04 ; 95 \% \mathrm{CI}:-0.13$ to 0.03 ) (Fig. 2c). In contrast, experimental warming increased MBC (+14.3\%; 95\% CI: 2.9-24.6\%), MBN (+20.1\%; 95\% CI: 2.0-45.1\%) and $\mathrm{NO}_{3}{ }^{-}-\mathrm{N}(+39.2 \%$; 95\% CI: 19.6-43.5\%) (Fig. 2c). A significant difference in the warming effect was observed between $\mathrm{MBC}$ and MBN $\left(Q_{M}=4.21, P<0.05\right)$ and between $\mathrm{NH}_{4}{ }^{+}-\mathrm{N}$ and $\mathrm{NO}_{3}{ }^{-}-\mathrm{N}$ $\left(Q_{M}=84.87, P<0.001\right)$.

The experimental warming did not change the DOC (mean effect size $=0.16 ; 95 \% \mathrm{CI}:-0.04$ to 0.40 ) but increased the net nitrogen mineralization rate by $49.2 \%$ (95\% CI: 38.1-62.3\%), the net nitrification rate by $56.0 \%$ (95\% CI: $51.4-66.1 \%$ ) and the DON by $39.2 \%$ (95\% CI: 19.6-43.5\%) (Fig. 3). There was a no difference in the response of the net nitrogen mineralization and net nitrification rates to warming $\left(Q_{M}=0.46, P>0.05\right)$.

The experimental warming had positive effects on soil invertase (+10.6\%; 95\% CI: 3.1-18.9\%) and protease (+4.2\%; 95\% CI: 3.8-32.4\%) (Fig. 3). In contrast, soil catalase (mean effect size $=0.30 ; 95 \% \mathrm{CI}$ : -0.01 to 0.07 ), urease (mean effect size $=-0.13 ; 95 \% \mathrm{CI}$ : -0.19 to 0.25 ) and polyphenol oxidase (mean effect size $=-0.075 ; 95 \% \mathrm{CI}$ : -0.180 to 0.002 ) did not change due to experimental warming (Fig. 3). In addition, the experimental warming increased the soil respiration by $33.6 \%$ (95\% CI: $11.1-43.6 \%$ ) (Fig. 3 ).

The warming duration did not correlate with the effects of warming on the soil carbon and nitrogen pools, MBC and MBN (Table 2). Similarly, the increased soil temperature had no correlations with the effects of warming on the soil nitrogen, MBC and MBN (Table 2). Although mean annual air temperature did not correlate with the effect of warming on soil carbon and nitrogen pools, it had a significant, negative relationship with the effect of warming on the soil MBC $(P=0.001)$ and MBN $(P=0.002)$ (Table 2).

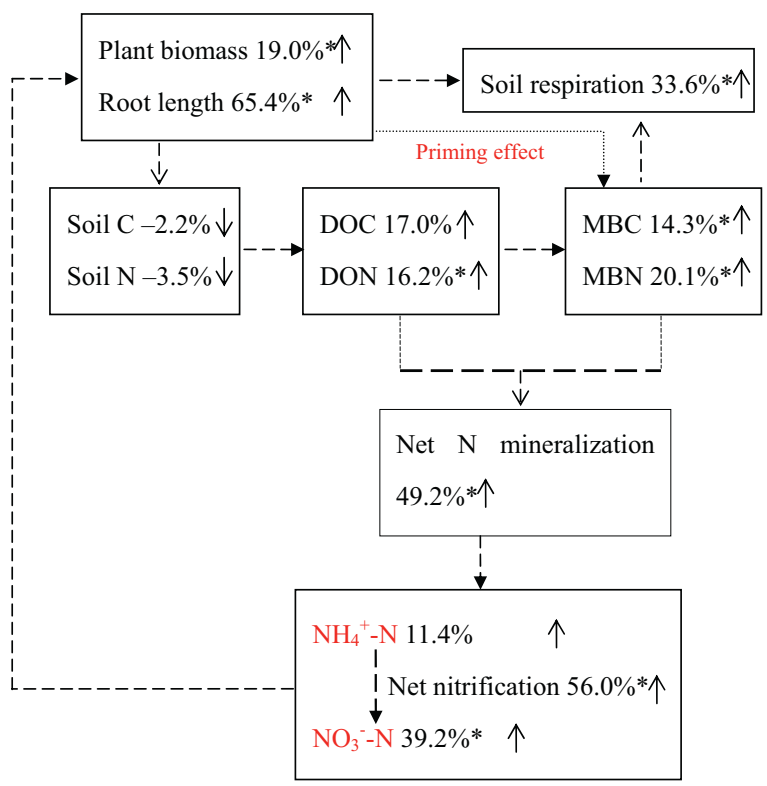

Fig. 4. Response of the soil carbon and nitrogen pools and their related biogeochemical processes to experimental warming from a meta-analysis of 25 studies on the Tibetan Plateau. $\uparrow$ and $\downarrow$ are positive and negative responses to warming, respectively. The numbers indicate the mean effect size. ${ }^{*} P<0.05$. MBC: soil microbial biomass carbon; MBN: soil microbial biomass nitrogen; DOC: dissolved organic carbon; DON: dissolved organic nitrogen; $\mathrm{NH}_{4}{ }^{+}-\mathrm{N}$ : ammonium nitrogen; $\mathrm{NO}_{3}{ }^{-}-\mathrm{N}$ : nitrate nitrogen.

\section{Discussion}

\subsection{Soil $C$ and $N$ pools}

The warming significantly increased the net nitrogen mineralization by $49.2 \%$ (Fig. 4), which was close to the magnitudes reported by previous meta-analyses (Bai et al., 2013; Lu et al., 2013a; Rustad et al., 2001). The warming-induced increase in the net nitrification (56.0\%, Fig. 4) appeared to be larger than a previous meta-analysis (32.2\%) (Bai et al., 2013), which was most likely because the forests had a greater net nitrification response to warming than the grassland/prairie and shrubland/heathland (Bai et al., 2013). In detail, all of the observations of net nitrification were derived from forests in our analysis, while those of Bai et al. (2013) were derived from all of the biomes mentioned above. The warming-induced increases in the net nitrogen mineralization and nitrification may increase plant biomass because the nitrogen availability in soil was generally one of the most vital limiting factors for plant growth in alpine regions (Lin et al., 2010). The ratio of MBC to MBN partially reflects the composition of soil microorganisms (Xiong et al., 2010), and the increased magnitude of MBN was much greater than that of $\operatorname{MBC}\left(Q_{M}=4.21, P<0.05\right)$. Therefore, we speculated that warming would change the composition of the soil microbial community.

We found a significant positive effect of warming on the microbial biomass in soil (Fig. 4) and a significant negative relationship between the effect size of the warming on the microbial biomass in soil and the mean annual air temperature (Table 2), indicating that the positive warming effects on soil microbial biomass in colder environments were generally greater than in warmer environments on the Tibetan Plateau. Bai et al. (2013) demonstrated that warming-induced reduction in labile carbon may result in the non-significant response of MBN to warming. However, warming did not affect DOC (Fig. 4), which is an important labile carbon pool (Lu et al., 2013a). These findings implied that DOC may not be the main limiting factors determining the increase of soil microbial biomass under warming condition on the Tibetan Plateau. Increases in plant biomass accumulation and root growth facilitated the growth of the soil microbial population and eventually the accumulation of soil microbial biomass (Barbhuiya et al., 2004; Dinakaran et al., 2011; Liu et al., 2011b Lu et al., 2013a).

The increase in the magnitude of $R_{\mathrm{s}}(+33.6 \%)$ due to warming in our meta-analysis was greater than that reported by previous meta-analyses (+9\% to +22.5\%) (Lu et al., 2013a; Rustad et al., 2001; Sun et al., 2011; Wu et al., 2011). The increases in the plant root respiration and soil microbial respiration likely resulted in the increase in the $R_{\mathrm{S}}$, whereas the increase in the soil microbial respiration likely caused a decrease in the organic matter in soil ( $\mathrm{Lu}$ et al., 2013a; Yan et al., 2011). In addition, decreases in soil carbon and nitrogen storage may also result from an increase in soil enzyme activity and a decrease in litter quantity due to climatic warming (Liu et al., 2011a; Pan et al., 2008; Xu et al., 2010a). However, neither the soil carbon nor nitrogen pools were significantly affected by the warming (Fig. 4), which was consistent with the previous meta-analyses (Bai et al., 2013; Lu et al., 2013a). This finding likely resulted from the fact that the increases in plant biomass and root growth (Fig. S1) may roughly offset the increase in soil microbial respiration.

\subsection{Different responses between forests and grasslands}

Previous meta-analyses indicated that forests were more sensitive to warming than grasslands in terms of $R_{\mathrm{S}}$ (Lu et al., 2013a; Rustad et al., 2001), net nitrogen mineralization and 
nitrification rates (Bai et al., 2013). The stronger response of these variables to warming in forests than in grasslands was attributed to the following causes: the effect of warming on the net nitrification was dependent on the soil moisture in the grasslands (Bai et al., 2013), and the negative response of soil moisture to warming in grasslands was greater than that in forests (Bai et al., 2013; Lu et al., 2013a). Soil respiration was positively correlated with soil moisture and soil drying can reduce the effect of warming on soil respiration (Liu et al., 2009; Shi et al., 2012). Thus, the experimental warming caused soil drying, which may offset the increased temperature effects in grasslands. In addition, Bai et al. (2013) attributed the stronger response of forests to the fact that most observations in forests were conducted in more temperaturelimited areas.

In contrast, $\mathrm{MBC}$ and $\mathrm{MBN}$ showed a significant positive response to warming only in the grasslands (Fig. 2). MBC and MBN respond quickly to changes in soil temperature and moisture (Alvarez et al., 1995; Skopp et al., 1990), implying that the experimental warming caused changes in the soil temperature and moisture that affect the microbial activity and change the microbial biomass in the soil. First, the positive effects of warming on the soil microbial biomass decreased with increasing mean annual air temperature (Table 2) and grasslands had a lower mean annual air temperature than forests in our meta-analysis (most $<3{ }^{\circ} \mathrm{C}$ vs. $>3{ }^{\circ} \mathrm{C}$ ). Second, soil drying may roughly offset the effect of warming on the microbial biomass in soil (Fu et al., 2012) and the negative effects of warming on the soil moisture in grasslands was greater than in forests (Bai et al., 2013; Lu et al., 2013a). Third, the effects of warming on the microbial biomass in soil did not change with the warming magnitude or warming duration (Table 2). Therefore, the different responses of the microbial biomass communities in the forests and grasslands may be attributed to the different mean annual air temperatures.

In addition, these results indicated that forests did not always show a stronger response to warming than grasslands. This finding was in line with recent meta-analyses which indicated that terrestrial ecosystems did not always have greater sensitivity in colder environments (Lu et al., 2013a; Wu et al., 2011).

\subsection{Influences of warming duration and raised soil temperature}

We did not find significant relationships between the warming duration and the sizes of the effects of the warming (Table 2), which may be observed because the soil carbon availability did not change, and the soil nitrogen availability increased in our metaanalysis. Our findings suggested that the effects of warming on gross and net primary production, net ecosystem exchange, ecosystem respiration, plant biomass, soil carbon and nitrogen, soil microbial biomass, net nitrogen mineralization and nitrification did not change with the warming duration (Bai et al., 2013; Lin et al., 2010; Lu et al., 2013a; Rustad et al., 2001; Wu et al., 2011) due to the significant, warming-induced increases in the labile carbon and nitrogen availability in the soil (Bai et al., 2013; Lu et al., 2013a; Rustad et al., 2001). In contrast, many studies indicated that the warming duration had a significant negative relationship between the warming effects and plant nitrogen uptake and $R_{\mathrm{s}}$ (Atkin et al., 2000; Bai et al., 2013; Melillo et al., 2002), which could be caused by the loss of labile carbon and nitrogen in soils (Luo et al., 2001; Melillo et al., 2002; Wu et al., 2011). Therefore, whether the effects of warming on carbon and nitrogen were correlated with the warming duration was likely dependent on the conditions of the labile carbon and nitrogen.

We did not find significant relationships between the warming magnitude and the sizes of the effects of warming on soil nitrogen, MBC or MBN (Table 2). This finding was in line with previous metaanalyses, which found that increased temperature was not significantly correlated with the effects of warming on $R_{\mathrm{S}}$ and soil carbon (Lu et al., 2013a), soil nitrogen and MBN (Bai et al., 2013).

\section{Conclusions}

Our meta-analysis indicated that both MBC and MBN exhibited stronger positive responses to warming in colder environments. Global warming may affect grasslands to a greater extent than forests in terms of MBC and MBN. However, warming did not affect soil carbon and nitrogen pools. Our findings should be useful for understanding the underlying mechanisms of the response of alpine soils to global warming.

\section{Acknowledgments}

We thank the editor and reviewers for their insightful and valuable comments, which greatly improved the quality of this manuscript. This work was funded by the National Natural Science Foundation of China (No. 41171084), Chinese Academy of Science Western Light Talents Program (Response of livestock carrying capability to climatic change and grazing in the alpine meadow of Northern Tibetan Plateau) and the Natural Science Foundation of Tibet Autonomous Region (Response of species richness and above-ground biomass to warming in the alpine meadow of Tibet).

\section{Appendix A. Supplementary data}

Supplementary data associated with this article can be found, in
the online version, at http://dx.doi.org/10.1016/j. apsoil.2014.11.012.

\section{References}

Alvarez, R., Santanatoglia, O.J., Garcia, R., 1995. Effects of temperature on soil microbial biomass and its metabolic quotient in situ under different tillage systems. Biol. Fert. Soils 19, 227-230.

Atkin, O.K., Edwards, E.J., Loveys, B.R., 2000. Response of root respiration to changes in temperature and its relevance to global warming. New Phytol. 147, 141-154.

Bai, E., Li, S.L., Xu, W.H., Li, W., Dai, W.W., Jiang, P., 2013. A meta-analysis of experimental warming effects on terrestrial nitrogen pools and dynamics. New Phytol. 199, 441-451.

Barbhuiya, A.R., Arunachalam, A., Pandey, H.N., Arunachalam, K., Khan, M.L., Nath, P. C., 2004. Dynamics of soil microbial biomass C, N and P in disturbed and undisturbed stands of a tropical wet-evergreen forest. Eur. J. Soil Biol. 40, 113-121.

Chen, Z., Yin, H.J., Wei, Y.Y., Liu, Q., 2010. Short-term effects of night warming and nitrogen addition on soil available nitrogen and microbial properties in subalpine coniferous forest, Western Sichuan, China. Chin. J. Plant Ecol. 34, 1254-1264 (in Chinese with English abstract).

Chen, H., Zhu, Q.A., Peng, C.H., Wu, N., Wang, Y.F., Fang, X.Q., Gao, Y.H., Zhu, D., Yang, G., Tian, J.Q., Kang, X.M., Piao, S.L., Ouyang, H., Xiang, W.H., Luo, Z.B., Jiang, H., Song, X.Z., Zhang, Y., Yu, G.R., Zhao, X.Q., Gong, P., Yao, T.D., Wu, J.H., 2013. The impacts of climate change and human activities on biogeochemical cycles on the Qinghai-Tibetan Plateau. Global Change Biol. 19, 2940-2955.

Dinakaran, J., Mehta, N., Krishnayya, N.S.R., 2011. Soil organic carbon dynamics in two functional types of ground cover (grasses and herbaceous) in the tropics. Curr. Sci. 101, 776-783.

Fu, G., Shen, Z., Zhang, X., Zhou, Y., 2012. Response of soil microbial biomass to shortterm experimental warming in alpine meadow on the Tibetan Plateau. Appl. Soil Ecol. 61, 158-160.

Fu, G., Zhang, X., Zhang, Y., Shi, P., Li, Y., Zhou, Y., Yang, P., Shen, Z., 2013. Experimental warming does not enhance gross primary production and above-ground biomass in the alpine meadow of Tibet. J. Appl. Remote Sens. doi:http://dx.doi. org/10.1117/1.JRS.7.073505.

Fu, G., Shen, Z.X., Sun, W., Zhong, Z.M., Zhang, X.Z., Zhou, Y.T., 2014. A meta-analysis of the effects of experimental warming on plant physiology and growth on the Tibetan Plateau. J. Plant Growth Regul. doi:http://dx.doi.org/10.1007/s00344014-9442-0 (in press)

Han, C., Liu, Q., Yang, Y., 2009. Short-term effects of experimental warming and enhanced ultraviolet-B radiation on photosynthesis and antioxidant defense of Picea asperata seedlings. Plant Growth Regul. 58, 153-162.

Hedges, L.V., Gurevitch, J., Curtis, P.S., 1999. The meta-analysis of response ratios in experimental ecology. Ecology 80, 1150-1156. 
Heng, T., 2011. The responses of soil carbon and nitrogen, microbial biomass carbon and nitrogen under alpine meadow of Qinghai-Tibet plateau to changing temperature and precipitation. Southwest University of China (in Chinese with English abstract).

IPCC, 2007. Climate change 2007: the scientific basis. In: Solomon, S., Qin, D., Manning, M., Chen, Z., Marquis, M., Averyt, K.B., Tignor, M., Miller, H.L. (Eds.), Contributions of Working Group I to the Fourth Assessment Report of the Intergovernmental Panel on Climate Change: The Physical Science Basis. Cambridge University Press, Cambridge.

Klein, J.A., Harte, J., Zhao, X.Q., 2007. Experimental warming, not grazing, decreases rangeland quality on the Tibetan Plateau. Ecol. Appl. 17, 541-557.

Li, N., Wang, G.X., Yang, Y., Gao, Y.H., Liu, G.S., 2011. Plant production, and carbon and nitrogen source pools, are strongly intensified by experimental warming in alpine ecosystems in the Qinghai-Tibet Plateau. Soil Biol. Biochem. 43, 942-953.

Li, N., Wang, G.X., Gao, Y.H., Wang, J.F., Liu, L.A., 2010. Effects of simulated warming on soil nutrients and biological characteristics of alpine meadow soil in the head waters region of the YangTZe River (in Chinese with English abstract). Acta Pedologica Sin. 47, 1214-1224.

Lin, D.L., Xia, J.Y., Wan, S.Q., 2010. Climate warming and biomass accumulation of terrestrial plants: a meta-analysis. New Phytol. 188, 187-198.

Lin, Q.Y., Xu, G.P., Su, A.L., Duan, J.C., Zhang, Z.H., Luo, C.Y., Wang, S.P., 2011a. Response of litter quality to warming in the alpine meadow on the Tibetan Plateau. Guihaia 31, 770-774.

Lin, X.W., Zhang, Z.H., Wang, S.P., Hu, Y.G., Xu, G.P., Luo, C.Y., Chang, X.F., Duan, J.C., Lin, Q.Y., Xu, B., Wang, Y.F., Zhao, X.Q., Xie, Z.B., 2011b. Response of ecosystem respiration to warming and grazing during the growing seasons in the alpine meadow on the Tibetan plateau. Agr. Forest Metrol. 151, 792-802.

Liu, L., Zhu, X., Sun, G., Luo, P., Wang, B., 2011a. Effects of simulated warming and fertilization on activities of soil enzymes in alpine meadow (in Chinese with English abstract). Pratacultural Sci. 28, 1405-1410.

Liu, Q., Yin, H.J., Chen, J.S., Zhao, C.Z., Cheng, X.Y., Wei, Y.Y., Lin, B., 2011b. Belowground responses of Picea asperata seedlings to warming and nitrogen fertilization in the eastern Tibetan Plateau. Ecol Res. 26, 637-648.

Liu, X.D., Chen, B.D., 2000. Climatic warming in the Tibetan Plateau during recent decades. Int. J. Climatol. 20, 1729-1742.

Liu, W.X., Zhang, Z., Wan, S.Q., 2009. Predominant role of water in regulating soil and microbial respiration and their responses to climate change in a semiarid grassland. Global Change Biol. 15, 184-195.

Lu, M., Zhou, X.H., Yang, Q., Li, H., Luo, Y.Q., Fang, C.M., Chen, J.K., Yang, X., Li, B., 2013a. Responses of ecosystem carbon cycle to experimental warming: a metaanalysis. Ecology 94, 726-738.

Lu, X.Y., Fan, J.H., Yan, Y., Wang, X.D., 2013b. Responses of soil $\mathrm{CO}_{2}$ fluxes to shortterm experimental warming in alpine steppe ecosystem, Northern Tibet. PLoS One 8, e59054.

Luo, Y.Q., Wan, S.Q., Hui, D.F., Wallace, L.L., 2001. Acclimatization of soil respiration to warming in a tall grass prairie. Nature 413, 622-625.

Luo, C.Y., Xu, G.P., Wang, Y.F., Wang, S.P., Lin, X.W., Hu, Y.G., Zhang, Z.H., Chang, X.F., Duan, J.C., Su, A.L., Zhao, X.Q., 2009. Effects of grazing and experimental warming on DOC concentrations in the soil solution on the Qinghai-Tibet plateau. Soil Biol. Biochem. 41, 2493-2500.

Luo, C.Y., Xu, G.P., Chao, Z.G., Wang, S.P., Lin, X.W., Hu, Y.G., Zhang, Z.H., Duan, J.C., Chang, X.F., Su, A.L., Li, Y.N., Zhao, X.Q., Du, M.Y., Tang, Y.H., Kimball, B., 2010. Effect of warming and grazing on litter mass loss and temperature sensitivity of litter and dung mass loss on the Tibetan plateau. Global Change Biol. 16, 1606-1617.

Melillo, J.M., Steudler, P.A., Aber, J.D., Newkirk, K., Lux, H., Bowles, F.P., Catricala, C., Magill, A., Ahrens, T., Morrisseau, S., 2002. Soil warming and carbon-cycle feedbacks to the climate system. Science 298, 2173-2176.

Miehe, G., Bach, K., Miehe, S., Kluge, J., Yang, Y.P., La, D., Co, S., Wesche, K., 2011. Alpine steppe plant communities of the Tibetan highlands. Appl. Veg. Sci. 14, 547-560.

Pan, X.L., Lin, B., Liu, Q., 2008. Effects of elevated temperature on soil organic carbon and soil respiration under subalpine coniferous forest in western Sichuan Province, China. Chin. J. Appl. Ecol. 19, 1637-1643 (in Chinese with English abstract).

Rosenberg, M.S., Adams, D.C., Gurevitch, J., 2000. Meta Win: Statistical Software for Meta-Analysis. Version 2. Sinauer Associates, Sunderland Massachusetts, USA.

Rui, Y.C., Wang, S.P., Xu, Z.H., Wang, Y.F., Chen, C.R., Zhou, X.Q., Kang, X.M., Lu, S.B., Hu, Y.G., Lin, Q.Y., Luo, C.Y., 2011. Warming and grazing affect soil labile carbon and nitrogen pools differently in an alpine meadow of the Qinghai-Tibet Plateau in China. J. Soil Sediment 11, 903-914.

Rustad, L.E., Campbell, J.L., Marion, G.M., Norby, R.J., Mitchell, M.J., Hartley, A.E., Cornelissen, J.H.C., Gurevitch, J., Gcte, N., 2001. A meta-analysis of the response of soil respiration, net nitrogen mineralization, and aboveground plant growth to experimental ecosystem warming. Oecologia 126, 543-562.

Shen, Z., Fu, G., Yu, C., Sun, W., Zhang, X., 2014. Relationship between the growing season maximum enhanced vegetation index and climatic factors on the Tibetan Plateau. Remote Sens. 6, 6765-6789.

Shi, F.S., Chen, H., Chen, H.F., Wu, Y., Wu, N., 2012. The combined effects of warming and drying suppress $\mathrm{CO}_{2}$ and $\mathrm{N}_{2} \mathrm{O}$ emission rates in an alpine meadow of the eastern Tibetan Plateau. Ecol. Res. 27, 725-733.

Shi, F.S., Wu, N., Wu, Y., 2010. Responses of plant growth and substance allocation of three dominant plant species to experimental warming in an alpine grassland, Northwestern Sichuan, China (in Chinese with English abstract). Chin. J. Plant Ecol. 34, 488-497.

Skopp, J., Jawson, M.D., Doran, J.W., 1990. Steady-state aerobic microbial activity as a function of soil water content. Soil Sci. Soc. Am. J. 54, 1619-1625.

Sun, J.F., Peng, C.H., St Onge, B., Berninger, F., McCaughey, H., Lei, X.D., 2011. Metaanalysis of the effects of soil warming on soil respiration in forest ecosystems. Pol. J. Ecol. 59, 709-715.

Wan, S.Q., Hui, D.F., Luo, Y.Q., 2001. Fire effects on nitrogen pools and dynamics in terrestrial ecosystems: a meta-analysis. Ecol. Appl. 11, 1349-1365.

Wang, B., Sun, G., Luo, P., Wang, M., Wu, N., 2011. Labile and recalcitrant carbon and nitrogen pools of an alpine meadow soil from the eastern Qinghai-Tibetan Plateau subjected to experimental warming and grazing. Acta Ecol. Sin. 31, 1506-1514 (in Chinese with English abstract).

Wang, S.P., Duan, J.C., Xu, G.P., Wang, Y.F., Zhang, Z.H., Rui, Y.C., Luo, C.Y., Xu, B., Zhu, X.X., Chang, X.F., Cui, X.Y., Niu, H.S., Zhao, X.Q., Wang, W.Y., 2012. Effects of warming and grazing on soil $\mathrm{N}$ availability, species composition, and ANPP in an alpine meadow. Ecology 93, 2365-2376.

Wu, Z.T., Dijkstra, P., Koch, G.W., Penuelas, J., Hungate, B.A., 2011. Responses of terrestrial ecosystems to temperature and precipitation change: a metaanalysis of experimental manipulation. Global Change Biol. 17, 927-942.

Xiong, P., Xu, Z.F., Lin, B., Liu, Q., 2010. Short-term response of winter soil respiration to simulated warming in a Pinus armandii plantation in the upper reaches of the Minjiang River, China. Chin. J. Plant Ecol. 34,1369-1376 (in Chinese with English abstract).

Xu, Z.F., Hu, R., Xiong, P., Wan, C.A., Cao, G., Liu, Q., 2010a. Initial soil responses to experimental warming in two contrasting forest ecosystems, Eastern Tibetan Plateau, China: nutrient availabilities, microbial properties and enzyme activities. Appl. Soil Ecol. 46, 291-299.

Xu, Z.F., Wan, C.A., Xiong, P., Tang, Z., Hu, R., Cao, G., Liu, Q., 2010b. Initial responses of soil $\mathrm{CO}_{2}$ efflux and $\mathrm{C}, \mathrm{N}$ pools to experimental warming in two contrasting forest ecosystems, Eastern Tibetan Plateau, China. Plant Soil 336, 183-195.

Xu, Z.F., Yin, H.J., Xiong, P., Wan, C., Liu, Q., 2012. Short-term responses of Picea asperata seedlings of different ages grown in two contrasting forest ecosystems to experimental warming. Environ. Exp. Bot. 77, 1-11.

Yan, L.M., Chen, S.P., Huang, J.H., Lin, G.H., 2011. Water regulated effects of photosynthetic substrate supply on soil respiration in a semiarid steppe. Global Change Biol. 17, 1990-2001.

Yang, Y., Wang, G.X., Yang, L.D., Guo, J.Y., 2013. Effects of Drought and Warming on Biomass, Nutrient Allocation, and Oxidative Stress in Abies fabri in Eastern Tibetan Plateau. J. Plant Growth Regul. 32, 298-306.

Yao, T.D., Liu, X.D., Wang, N.L., Shi, Y.F., 2000. Amplitude of climatic changes in Qinghai-Tibetan Plateau. Chin. Sci. Bull. 45, 1236-1243.

Yin, H.J., Chen, Z., Liu, Q., 2012. Effects of experimental warming on soil N transformations of two coniferous species, Eastern Tibetan Plateau, China. Soil Biol. Biochem. 50, 77-84.

Yin, H.J., Lai, T., Cheng, X.Y., Jiang, X.M., Liu, Q., 2008a. Warming effects on growth and physiological of seedlings of Betula Albo-sinensis and Abries Faxonianaunde two contrasting light conditions in subalpine coniferous forest of western Sichuan, China (in Chinese with English abstract). Chin. J Plant Ecol. 32, 1072-1083.

Yin, H.J., Li, Y.F., Xiao, J., Xu, Z.F., Cheng, X.Y., Liu, Q., 2013. Enhanced root exudation stimulates soil nitrogen transformations in a subalpine coniferous forest under experimental warming. Global Change Biol. 19, 2158-2167.

Yin, H.J., Liu, Q., Lai, T., 2008b. Warming effects on growth and physiology in the seedlings of the two conifers Picea asperata and Abies faxoniana under two contrasting light conditions. Ecol. Res. 23, 459-469.

Yu, C.Q., Shen, Z.X., Zhang, X.Z., Sun, W., Fu, G., 2014. Response of soil C and N, dissolved organic $\mathrm{C}$ and $\mathrm{N}$, and inorganic $\mathrm{N}$ to short-term experimental warming in an alpine meadow on the Tibetan Plateau. Sci. World J. 2014 doi:http://dx.doi.org/10.1155/2014/152576.

Zhang, X.Z., Zhang, Y.G., Zhoub, Y.H., 2000. Measuring and modelling photosynthetically active radiation in Tibet Plateau during April-October. Agr. Forest Meteorol. 102, 207-212. 